\title{
ID4 wt Allele
}

National Cancer Institute

\section{Source}

National Cancer Institute. ID4 wt Allele. NCI Thesaurus. Code C125499.

Human ID4 wild-type allele is located in the vicinity of $6 p 22.3$ and is approximately $5 \mathrm{~kb}$ in length. This allele, which encodes DNA-binding protein inhibitor ID-4 protein, is involved in the inhibition of basic helix-loop-helix transcription factors. 